\title{
Methanosaeta harundinacea sp. nov., a novel acetate-scavenging methanogen isolated from a UASB reactor
}

\author{
Correspondence \\ Xiuzhu Dong \\ dongxz@sun.im.ac.cn
}

\author{
Kai Ma, ${ }^{1,2}$ Xiaoli Liu ${ }^{1}$ and Xiuzhu Dong ${ }^{1}$ \\ ${ }^{1}$ State Key Laboratory of Microbial Resources, Institute of Microbiology, Chinese Academy of \\ Sciences, Beijing 100080, P. R. China \\ ${ }^{2}$ Graduate School, Chinese Academy of Sciences, Beijing 100049, P. R. China
}

\begin{abstract}
Two methanogenic strains, $8 \mathrm{Ac}^{\top}$ and $6 \mathrm{Ac}$, were isolated from an upflow anaerobic sludge blanket reactor treating beer-manufacture wastewater in Beijing, China. Cells of strains $8 \mathrm{Ac}^{\top}$ and $6 \mathrm{Ac}$ were rod-shaped $(0 \cdot 8-1 \cdot 0 \times 3-5 \mu \mathrm{m})$ and non-motile, occurring singly or in pairs; however, at high cell density the cells were arranged in long chains within a common sheath. The two strains used acetate exclusively for growth and methane production. The specific growth rate of strain $8 \mathrm{Ac}^{\top}$ was $0.030 \mathrm{~h}^{-1}$ when growing in acetate $(20 \mathrm{mM})$ at $37^{\circ} \mathrm{C}$. The temperature range for growth was $25-45^{\circ} \mathrm{C}$, with the fastest growth at $34-37^{\circ} \mathrm{C}$. The $\mathrm{pH}$ range for growth and methane production was $6 \cdot 5-9 \cdot 0$, with the fastest growth at $\mathrm{pH} 7 \cdot 2-7 \cdot 6$. The $\mathrm{G}+\mathrm{C}$ content of genomic DNA of strain $8 \mathrm{Ac}^{\top}$ was $55 \cdot 7$ mol\%. Phylogenetic analysis based on $16 \mathrm{~S}$ rRNA gene sequence similarity showed that the novel strains clustered with Methanosaeta species; the 16S rRNA gene sequence similarities between strain $8 \mathrm{Ac}^{\top}$ and Methanosaeta concilii DSM 3013 and 'Methanosaeta thermophila' DSM 6194 were 92.5 and $87.3 \%$, respectively. The sequence similarity levels of $m c r A$, the gene encoding the $\alpha$-subunit of methyl-coenzyme $M$ reductase, and of the deduced amino acids of $m c r A$, between strain $8 \mathrm{Ac}^{\top}$ and Methanosaeta concilii DSM $3671^{\top}$ were 36 and $78.9 \%$, respectively. Based on the phylogenetic and phenotypic analyses, the novel species Methanosaeta harundinacea sp. nov. is proposed, with strain $8 \mathrm{Ac}^{\top}$ $\left(=\operatorname{JCM} 13211^{\top}=\right.$ CGMCC $\left.1.5026^{\top}\right)$ as the type strain.
\end{abstract}

Acetate is an important substrate for methanogenesis in anaerobic bioreactors and two-thirds or more of the methane produced in anaerobic bioreactors is derived from acetate (Zinder, 1993). All described acetate-using methanogens belong to the order Methanosarcinales. Among these, Methanosaeta species can be distinguished from members of the other genera by their exclusive use of acetate as a substrate for producing methane and by their rod-shaped cells, instead of coccoid or pseudosarcinal cells such as those of Methanosarcina species. In addition, in contrast to Methanosarcina species, Methanosaeta strains are favoured in environments with low concentrations of acetate (Huser et al., 1982). To date, only two species have been described in the genus Methanosaeta, Methanosaeta concilii (Patel \&

Published online ahead of print on 9 September 2005 as DOI 10.1099/ijs.0.63887-0.

Abbreviation: UASB, upflow anaerobic sludge blanket.

The GenBank/EMBL/DDBJ accession numbers for the 16S rRNA gene sequences of Methanosaeta harundinacea $8 A c^{\top}$ and $6 A c$ are AY817738 and AY970347, respectively, and those for the partial sequences of mcrA of Methanosaeta harundinacea $8 \mathrm{Ac}^{\top}$ and $6 \mathrm{Ac}$ are AY970348 and AY970349, respectively.
Sprott, 1990) and 'Methanosaeta thermophila' (Kamagata et al., 1992; Boone \& Kamagata, 1998), although investigations based on culture-independent approaches have indicated that Methanosaeta strains occur widely (Lueders et al., 2001; Zengler et al., 1999). Ultrastructural analysis of granules from upflow anaerobic sludge blanket (UASB) reactors using scanning and transmission electron microscopy has also shown numerous Methanosaeta-like cells, implying that they could play important roles in methanogenesis (Guiot et al., 1992; MacLeod et al., 1990; GonzalezGil et al., 2001).

During a survey of the microbial community of a mesophilic methane-producing UASB reactor in Beijing, China, we isolated two strains of rod-shaped methanogens that produced methane exclusively from acetate. Phylogenetically, the strains were affiliated to the genus Methanosaeta; however, they were distantly related to the existing species of the genus. Moreover, their cells were rod-shaped instead of in a filament. Based on the phylogenetic and phenotypic data, a novel species of Methanosaeta is proposed.

Pre-reduced basal medium was prepared as described by Huser et al. (1982) and sodium acetate (20 mM), yeast 
extract $(0.05 \%, \mathrm{w} / \mathrm{v})$ and peptone $(0.05 \%, \mathrm{w} / \mathrm{v})$ were added to form complete medium. The medium was dispensed in screw-capped tubes sealed with butyl rubber stoppers and the gas phase was $\mathrm{N}_{2} / \mathrm{CO}_{2}\left(80: 20,1 \cdot 01 \times 10^{5}\right.$ $\mathrm{Pa}$ ) for routine cultivation unless indicated. All inoculations and transfers were done with syringes and needles and all cultures were incubated at $37^{\circ} \mathrm{C}$ in the dark.

For enrichment of the acetate-using methanogenic culture, UASB granules for treating beer-manufacture wastewater in Beijing were inoculated and suspended with a vortex, and then serially diluted in complete medium containing $0.5 \mathrm{~g}$ penicillin $\mathrm{l}^{-1}$ (final concentration) to inhibit bacterial growth. Methanogenic dilution cultures were verified by methane production and acetate consumption after cultivation for a few weeks. This manipulation was repeated several times until pure cultures were obtained. Culture purity was confirmed periodically by monitoring cell morphology using normal bright-field microscopy, as well as by lack of growth in a rich medium, such as peptone/yeast extract/ glucose liquid.

Cells of strain $8 \mathrm{Ac}^{\mathrm{T}}$ in exponential growth phase were used for morphological examination under a transmission electron microscope (H-600A; Hitachi), after being coated with palladium/iridium alloy with a high vacuum evaporator (HUS-5GB; Hitachi). Cell motility was observed with a phase-contrast microscope (BH-2; Olympus). Cells from an exponential-phase culture were incubated in $1 \%$ SDS and distilled water as a hypotonic solution to check the susceptibility to lysis (Boone \& Whitman, 1988) and with proteinase $\mathrm{K}\left(50 \mu \mathrm{g} \mathrm{ml}^{-1}\right)$ to break the cell-enclosure sheath. Cell lysis or sheath breakage was determined microscopically, with untreated cells as a control. Physiological studies, such as substrate utilization, growth factor requirement, $\mathrm{pH}$ range, growth temperature range and $\mathrm{NaCl}$ tolerance were performed as described previously ( $\mathrm{Ma}$ et al., 2005). Methane production and substrate degradation were measured as described by Zhang et al. (2004). Formate cleavage was determined by measuring formate after culture for 20 days in basal medium containing formate $(10 \mathrm{mM})$. Formate was detected at $242 \mathrm{~nm}$ by HPLC (Waters model 1525). A reverse-phase HPLC (ODS Hypersil; Hewlett Packard) mobile phase of acetonitrile/water $(30: 70, \mathrm{v} / \mathrm{v})$

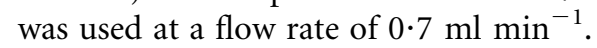

Genomic DNA extraction and purification were performed according to Jarrell et al. (1992), with a 11 culture. The $\mathrm{G}+\mathrm{C}$ content was determined by using the thermal denaturation method (Owen \& Pitcher, 1985), with Escherichia coli $\mathrm{K}-12$ as the reference, with a UV800 spectrophotometer (Beckman).

The 16S rRNA gene was amplified from the genomic DNA as described previously (Furlong et al., 2002). A partial fragment of the gene encoding the $\alpha$-subunit of methylcoenzyme $\mathrm{M}$ reductase $(\mathrm{mcr} A)$ was amplified according to Lueders et al. (2001). Purified PCR products of the 16S rRNA gene of $1400 \mathrm{bp}$ in length and a partial fragment of
mcrA of $500 \mathrm{bp}$ in length were cloned into the vector pUCm-T, and sequenced by Bioasia Company (Beijing).

Sequences in GenBank similar to those of the 16S rRNA gene and mcrA partial fragment were determined using the BLASTN algorithm. The best matching sequences were retrieved from the database and aligned and similarity analysis was performed with CLUSTAL_X (Thompson et al., 1997). Phylogenetic trees were constructed using MEGA 2.1 software (Kumar et al., 2001).

Cells of strains $8 \mathrm{Ac}^{\mathrm{T}}$ and $6 \mathrm{Ac}$ were rod-shaped $(0 \cdot 8-1 \cdot 0 \times 3-$ $5 \mu \mathrm{m}$; Fig. 1) and occurred singly or in pairs; however, at high cell density when grown in high concentrations of acetate $(>100 \mathrm{mM})$, the cells were arranged as a chain within a common sheath. Cells of strains $8 \mathrm{Ac}^{\mathrm{T}}$ and $6 \mathrm{Ac}$ were non-motile, Gram-variable and resisted disruption by $1 \%$ SDS $(\mathrm{w} / \mathrm{v})$ or hypotonic solution. However, cell-chain sheaths were partly destroyed by proteinase $\mathrm{K}\left(50 \mu \mathrm{g} \mathrm{ml}^{-1}\right)$, indicating a proteinaceous composition. The two strains were strictly anaerobic and growth was completely inhibited in air. Acetate was the only substrate tested to support growth and methane production, at concentrations of acetate of $2-350 \mathrm{mM}$. None of the following substrates tested was used for growth or methane production: $\mathrm{H}_{2} / \mathrm{CO}_{2}$, methanol, ethanol, trimethylamine, isobutanol and isopropanol (each $20 \mathrm{mM}$ ). Moreover, formate was not cleaved to hydrogen and carbon dioxide. Yeast extract $(0 \cdot 05-1 \%$, w/v) or peptone $(0.05-1 \%, w / v)$ was required for growth, whereas vitamins were not essential, in contrast to some Methanosaeta strains, for which yeast extract might be inhibitory (Touzel et al., 1988). Growth of strains $8 \mathrm{Ac}^{\mathrm{T}}$ and $6 \mathrm{Ac}$ was observed at $25-45^{\circ} \mathrm{C}$, with the fastest growth occurring at $34-37^{\circ} \mathrm{C}$. The $\mathrm{pH}$ range for growth was $6 \cdot 5-9 \cdot 0$, with the fastest growth at $\mathrm{pH} 7 \cdot 2-7 \cdot 6$. The specific

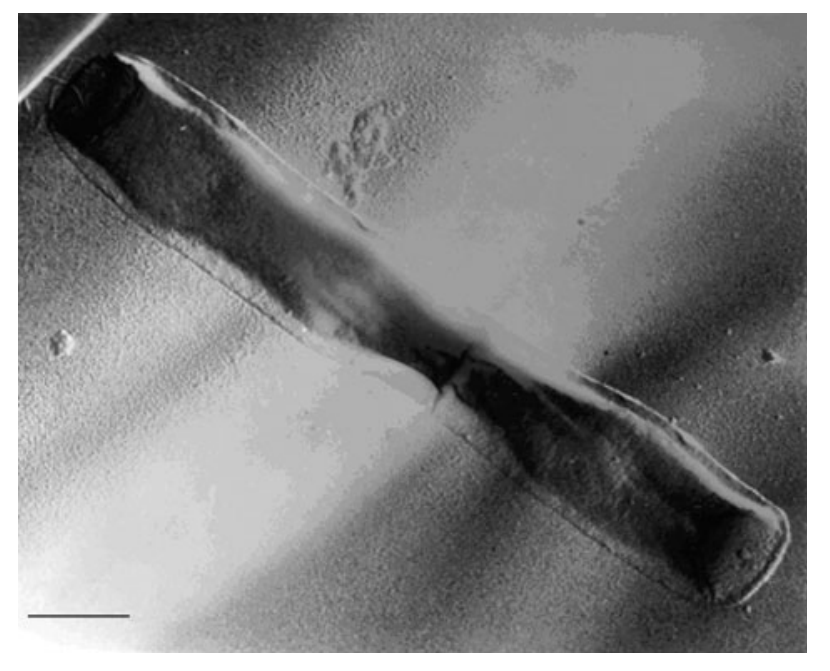

Fig. 1. Transmission electron micrograph of cells of Methanosaeta harundinacea strain $8 \mathrm{Ac}^{\top}$ grown in $20 \mathrm{mM}$ acetate for 20 days. Bar, $1 \mu \mathrm{m}$. 


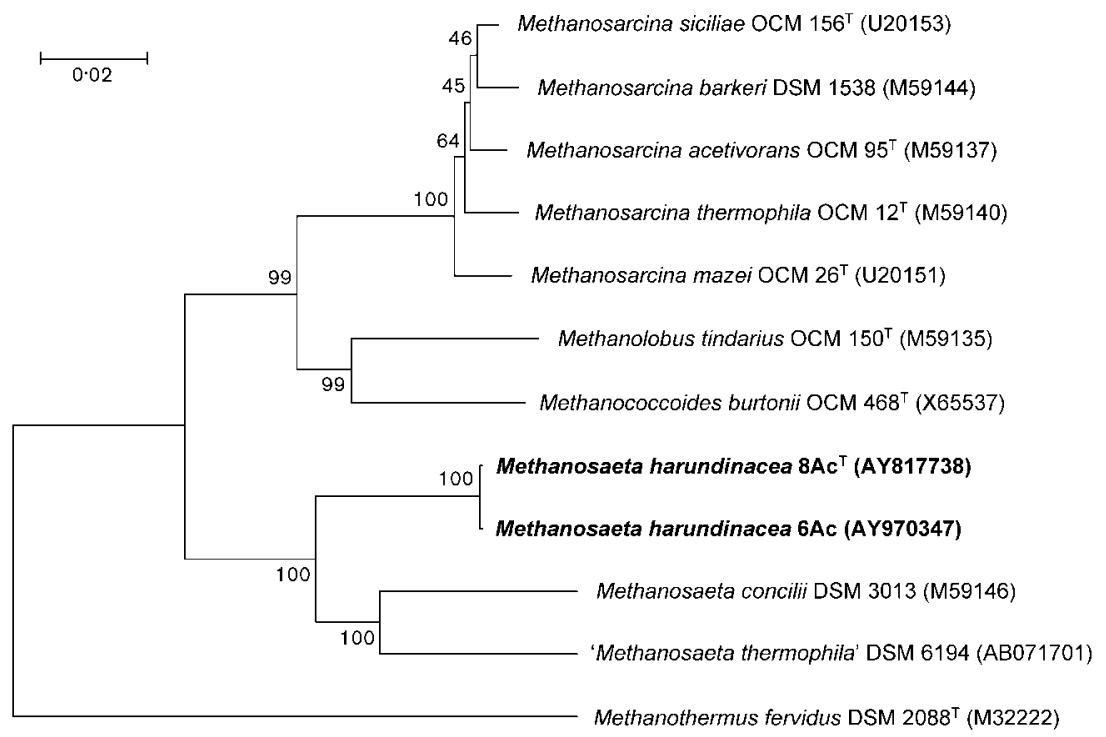

Fig. 2. Phylogenetic tree showing the position of strain $8 \mathrm{Ac}^{\top}$ amongst other members of the order Methanosarcinales. Based on 16S rRNA gene sequences (consensus length $1350 \mathrm{bp}$ ), the tree was constructed by using the neighbour-joining method and rooted with Methanothermus fervidus DSM $2088^{\top}$. The topology of the tree was estimated by bootstrap analysis based on 1000 replications. Numbers at branch points are percentages supported by bootstrap evaluation. GenBank accession numbers are given in parentheses. Bar, $2 \%$ sequence divergence.

growth rate of strain $8 \mathrm{Ac}^{\mathrm{T}}$ in complete medium at $37^{\circ} \mathrm{C}$ was $0 \cdot 030 \mathrm{~h}^{-1}$ (doubling time $28 \mathrm{~h}$ ), whereas the specific growth rate in acetate-containing basal medium with addition of yeast extract, peptone or tryptone $(0 \cdot 05 \%$, w/v) was $0 \cdot 016,0 \cdot 013$ and $0 \cdot 0045 \mathrm{~h}^{-1}$, respectively. The $\mathrm{G}+\mathrm{C}$ content of the genomic DNA of strain $8 \mathrm{Ac}^{\mathrm{T}}$ was $55 \cdot 7 \mathrm{~mol} \%$.

Phylogenetic analysis based on a consensus 1350 bp length of $16 \mathrm{~S}$ rRNA gene sequences (Fig. 2) showed $99.5 \%$ similarity between the two novel strains $8 \mathrm{Ac}^{\mathrm{T}}$ and $6 \mathrm{Ac}$, indicating that they represented a single species; however, similarities of only 92.5 and $87 \cdot 3 \%$ were obtained between strain $8 \mathrm{Ac}^{\mathrm{T}}$ and Methanosaeta concilii DSM 3013 and 'Methanosaeta thermophila' DSM 6194, respectively. In addition to $16 \mathrm{~S}$ rRNA gene sequence analysis, $m c r A$ gene sequences have also been used as a phylogenetic tool for the order Methanosarcinales; similarity levels among different species of the same genus range from $87 \cdot 5$ to $93 \cdot 8 \%$
(Springer et al., 1995). A phylogenetic tree (Fig. 3) was constructed based on deduced amino acid sequences of the $m c r A$ gene, including those of strain $8 \mathrm{Ac}^{\mathrm{T}}$ and related methanogens. The similarities of the partial fragments of $m c r A$ and deduced amino acid sequences between strain $8 \mathrm{Ac}^{\mathrm{T}}$ and Methanosaeta concilii DSM $3671^{\mathrm{T}}$ were 36 and $78.9 \%$, respectively. Phylogenetic analysis based on either the $16 \mathrm{~S}$ rRNA gene or mcrA indicated that strain $8 \mathrm{Ac}^{\mathrm{T}}$ represented a novel species of the genus Methanosaeta. In addition, strain $8 \mathrm{Ac}^{\mathrm{T}}$ also differed from other species in cell shape and $\mathrm{G}+\mathrm{C}$ content. Differential phenotypic characteristics of strain $8 \mathrm{Ac}^{\mathrm{T}}$ and other Methanosaeta species are shown in Table 1.

Based on morphological, physiological and phylogenetic data, we propose that the newly isolated strains $8 \mathrm{Ac}^{\mathrm{T}}$ and 6 Ac represent a novel species of the genus Methanosaeta, with the name Methanosaeta harundinacea sp. nov.

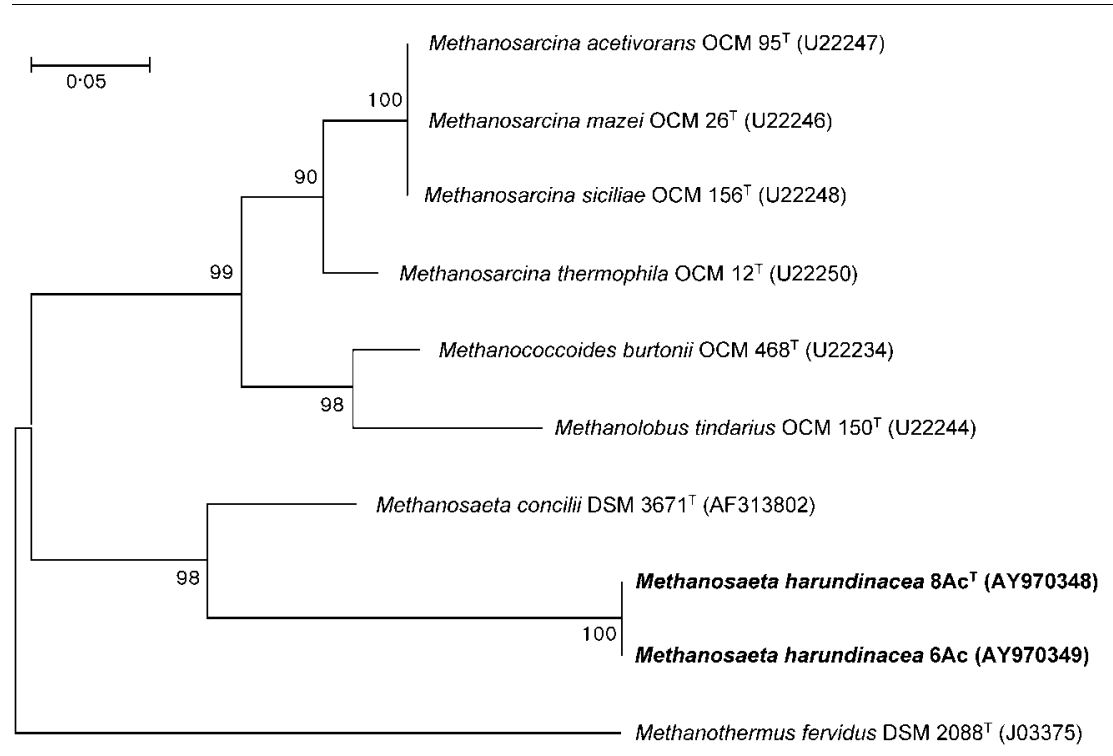

Fig. 3. Phylogenetic tree based on $m c r A$ gene sequences showing the position of strain $8 \mathrm{Ac}^{\top}$ amongst other members of the order Methanosarcinales. Based on consensus lengths of 165 deduced amino acids from $495 \mathrm{bp}$ of $m c r A$ sequences, the tree was constructed by using the neighbourjoining method and rooted with Methanothermus fervidus DSM $2088^{\top}$. The topology of the tree was estimated by bootstrap analysis based on 1000 replications. Numbers at branch points are percentages supported by bootstrap evaluation. GenBank accession numbers are given in parentheses. Bar, $5 \%$ sequence divergence. 
Table 1. Differential characteristics between Methanosaeta harundinacea sp. nov. $8 \mathrm{Ac}^{\top}$ and other species of Methanosaeta

Species: 1, Methanosaeta harundinacea $8 \mathrm{Ac}^{\mathrm{T}}$; 2, Methanosaeta concilii DSM $3671^{\mathrm{T}}$ [data from Patel \& Sprott (1990)]; 3, 'Methanosaeta thermophila' DSM 6194 (Kamagata et al., 1992). Abbreviations: PEP, peptone; SF, sludge fluid; YE, yeast extract; ND, not determined.

\begin{tabular}{|c|c|c|c|}
\hline Characteristic & 1 & 2 & 3 \\
\hline Cell width $(\mu \mathrm{m})$ & $0 \cdot 8-1 \cdot 0$ & $0 \cdot 8$ & $0 \cdot 8-1 \cdot 3$ \\
\hline $\begin{array}{l}\text { Cell arrangement in } 20 \mathrm{mM} \\
\text { acetate (length) }\end{array}$ & $\begin{array}{l}\text { Single or in } \\
\text { pairs }\end{array}$ & $\begin{array}{l}\text { Long chain in a } \\
\text { sheath }(>100 \mu \mathrm{m})\end{array}$ & $\begin{array}{l}\text { Short chain } \\
\qquad(10-100 \mu \mathrm{m})\end{array}$ \\
\hline \multicolumn{4}{|l|}{ Temperature: } \\
\hline Range $\left({ }^{\circ} \mathrm{C}\right)$ & $25-45$ & $10-45$ & ND \\
\hline Optimum $\left({ }^{\circ} \mathrm{C}\right)$ & $34-37$ & $35-40$ & $55-60$ \\
\hline \multicolumn{4}{|l|}{ pH: } \\
\hline Range & $6 \cdot 5-9 \cdot 0$ & $6 \cdot 6-7 \cdot 8$ & ND \\
\hline Optimum & $7 \cdot 2-7 \cdot 6$ & $7 \cdot 1-7 \cdot 5$ & approx. $7 \cdot 0$ \\
\hline Growth factor requirement & YE, PEP & SF, vitamin & SF \\
\hline Inhibitory factor & ND & YE $(0 \cdot 06 \%, w / v)$ & ND \\
\hline Doubling time $(\mathrm{h})$ & 28 & 65 & ND \\
\hline $\mathrm{G}+\mathrm{C}$ content $(\mathrm{mol} \%)$ & $55 \cdot 7\left(T_{\mathrm{m}}\right)$ & $50 \cdot 3\left(T_{\mathrm{m}}\right)$ & $52 \cdot 7$ (HPLC) \\
\hline
\end{tabular}

\section{Description of Methanosaeta harundinacea sp. nov.}

Methanosaeta harundinacea (ha.run.di.na'ce.a. L. fem. adj. harundinacea like a reed, referring to the cell shape of a reed stem).

Cells are rod-shaped $(0 \cdot 8-1 \cdot 0 \times 3-5 \mu \mathrm{m})$, occurring singly or in pairs; however, they are arranged as a chain within a common sheath at high cell density when grown in high concentrations of acetate $(>100 \mathrm{mM})$. Gram-variable. Non-motile. Cells are resistant to lysis by $1 \%$ SDS (w/v) and hypotonic solution, whereas the sheath of the long chain is partly destroyed by proteinase $\mathrm{K}\left(50 \mu \mathrm{g} \mathrm{ml}^{-1}\right)$. Methanogenic. Acetate is the exclusive tested substrate for growth and methanogenesis. No growth on or methane production from $\mathrm{H}_{2} / \mathrm{CO}_{2}$, formate, methanol, ethanol, trimethylamine, isobutanol or isopropanol. Formate is not cleaved to hydrogen and carbon dioxide. Yeast extract or peptone are required for growth, but not vitamins. The temperature range for growth is $25-45^{\circ} \mathrm{C}$, with optimal growth at $34-37^{\circ} \mathrm{C}$. The $\mathrm{pH}$ range for growth is $6 \cdot 5-9 \cdot 0$ and the optimum $\mathrm{pH}$ is $7 \cdot 2-7 \cdot 6$. The DNA G $+\mathrm{C}$ content of the type strain is $55 \cdot 7 \mathrm{~mol} \%\left(T_{\mathrm{m}}\right)$.

The type strain, $8 \mathrm{Ac}^{\mathrm{T}}$ ( = JCM $13211^{\mathrm{T}}=$ CGMCC $1.5026^{\mathrm{T}}$ ), was isolated from granules from a UASB anaerobic digester treating beer-manufacture wastewater.

\section{Acknowledgements}

This research was supported by grants from NSFC (30370001) and the National High Technology Program of China (863).

\section{References}

Boone, D. R. \& Kamagata, Y. (1998). Rejection of the species Methanothrix soehngenii ${ }^{\mathrm{VP}}$ and the genus Methanothrix ${ }^{\mathrm{VP}}$ as nomina confusa, and transfer of Methanothrix thermophila ${ }^{\mathrm{VP}}$ to the genus Methanosaeta $^{\mathrm{VP}}$ as Methanosaeta thermophila comb. nov. Request for an Opinion. Int J Syst Bacteriol 48, 1079-1080.

Boone, D. R. \& Whitman, W. B. (1988). Proposal of minimal standards for describing new taxa of methanogenic bacteria. Int $J$ Syst Bacteriol 38, 212-219.

Furlong, M. A., Singleton, D. R., Coleman, D. C. \& Whitman, W. B. (2002). Molecular and culture-based analyses of prokaryotic communities from an agricultural soil and the burrows and casts of the earthworm Lumbricus rubellus. Appl Environ Microbiol 68, $1265-1279$.

Gonzalez-Gil, G., Lens, P. N. L., Van Aelst, A., Van As, H., Versprille, A. I. \& Lettinga, G. (2001). Cluster structure of anaerobic aggregates of an expanded granular sludge bed reactor. Appl Environ Microbiol 67, 3683-3692.

Guiot, S. R., Pauss, A. \& Costerton, J. W. (1992). A structured model of the anaerobic granule consortium. Water Sci Technol 25 (7-8), 1-10.

Huser, B. A., Wuhrmann, K. \& Zehnder, A. J. B. (1982). Methanothrix soehngenii gen. nov. sp. nov., a new acetotrophic non-hydrogenoxidizing methane bacterium. Arch Microbiol 132, 1-9.

Jarrell, K. F., Faguy, D., Hebert, A. M. \& Kalmokoff, M. L. (1992). A general method of isolating high molecular weight DNA from methanogenic archaea (archaebacteria). Can J Microbiol 38, 65-68.

Kamagata, Y., Kawasaki, H., Oyaizu, H., Nakamura, K., Mikami, E., Endo, G., Koga, Y. \& Yamasato, K. (1992). Characterization of three thermophilic strains of Methanothrix ("Methanosaeta") thermophila sp. nov. and rejection of Methanothrix ("Methanosaeta") thermoacetophila. Int J Syst Bacteriol 42, 463-468.

Kumar, S., Tamura, K., Jakobsen, I. B. \& Nei, M. (2001). MEGA2: Molecular Evolutionary Genetics Analysis software. Arizona State University, Tempe, AZ, USA.

Lueders, T., Chin, K. J., Conrad, R. \& Friedrich, M. (2001). Molecular analyses of methyl-coenzyme $M$ reductase $\alpha$-subunit ( $m c r A$ ) genes in rice field soil and enrichment cultures reveal the methanogenic phenotype of a novel archaeal lineage. Environ Microbiol 3, 194-204.

Ma, K., Liu, X. \& Dong, X. (2005). Methanobacterium beijingense sp. nov., a novel methanogen isolated from anaerobic digesters. Int J Syst Evol Microbiol 55, 325-329. 
MacLeod, F. A., Guiot, S. R. \& Costerton, J. W. (1990). Layered structure of bacterial aggregates produced in an upflow anaerobic sludge bed and filter reactor. Appl Environ Microbiol 56, 1598-1607.

Owen, R. J. \& Pitcher, D. (1985). Current methods for estimating DNA base composition and levels of DNA-DNA hybridization. In Chemical Methods in Bacterial Systematics, pp. 67-93. Edited by M. Goodfellow \& D. E. Minnikin. London: Academic Press.

Patel, G. B. \& Sprott, G. D. (1990). Methanosaeta concilii gen. nov., sp. nov. ("Methanothrix concilii") and Methanosaeta thermoacetophila nom. rev., comb. nov. Int J Syst Bacteriol 40, 79-82.

Springer, E., Sachs, M. S., Woese, C. R. \& Boone, D. R. (1995). Partial gene sequences for the a subunit of methyl-coenzyme $M$ reductase ( $\mathrm{mcr}$ I) as a phylogenetic tool for the family Methanosarcinaceae. Int J Syst Bacteriol 45, 554-559.

Thompson, J. D., Gibson, T. J., Plewniak, F., Jeanmougin, F. \& Higgins, D. G. (1997). The CLUSTAL_X Windows interface: flexible strategies for multiple sequence alignment aided by quality analysis tools. Nucleic Acids Res 25, 4876-4882.

Touzel, J. P., Prensier, G., Roustan, J. L., Thomas, I., Dubourguier, H. C. \& Albagnac, G. (1988). Description of a new strain of Methanothrix soehngenii and rejection of Methanothrix concilii as a synonym of Methanothrix soehngenii. Int J Syst Bacteriol 38, 30-36.

Zengler, K., Richnow, H. H., Rosselló-Mora, R., Michaelis, W. \& Widdel, F. (1999). Methane formation from long-chain alkanes by anaerobic microorganisms. Nature 401, 266-269.

Zhang, C., Liu, X. \& Dong, X. (2004). Syntrophomonas curvata sp. nov., an anaerobe that degrades fatty acids in co-culture with methanogens. Int J Syst Evol Microbiol 54, 969-973.

Zinder, S. H. (1993). Physiological ecology of methanogens. In Methanogenesis: Ecology, Physiology, Biochemistry and Genetics, pp. 128-206. Edited by J. G. Ferry. New York: Chapman \& Hall. 